Article

\title{
Revised Environmental Kuznets Curve for V4 Countries and Baltic States
}

\author{
Mihaela Simionescu $^{1}$ (D) Adam Wojciechowski ${ }^{2}$ (D) Arkadiusz Tomczyk $^{2}$ (D) and Marcin Rabe ${ }^{3, *}$ \\ 1 Institute for Economic Forecasting, Romanian Academy, 50711 Bucharest, Romania; \\ mihaela.simionescu@ipe.ro \\ 2 Institute of Information Technology, Lodz University of Technology, 90-924 Łódź, Poland; \\ adam.wojciechowski@p.lodz.pl (A.W.); arkadiusz.tomczyk@p.lodz.pl (A.T.) \\ 3 Institute of Management, University of Szczecin, 71-004 Szczecin, Poland \\ * Correspondence: marcin.rabe@usz.edu.pl
}

Citation: Simionescu, M.;

Wojciechowski, A.; Tomczyk, A.;

Rabe, M. Revised Environmental Kuznets Curve for V4 Countries and Baltic States. Energies 2021, 14, 3302. https://doi.org/10.3390/en14113302

Academic Editors: Sergey Zhironkin and Josef Maroušek

Received: 19 April 2021

Accepted: 31 May 2021

Published: 4 June 2021

Publisher's Note: MDPI stays neutral with regard to jurisdictional claims in published maps and institutional affiliations.

Copyright: (c) 2021 by the authors. Licensee MDPI, Basel, Switzerland. This article is an open access article distributed under the terms and conditions of the Creative Commons Attribution (CC BY) license (https:// creativecommons.org/licenses/by/ $4.0 /)$.

\begin{abstract}
Sustainable development can be achieved when economic development does not produce environmental deterioration. In this context, the aim of the paper is to evaluate the effects of economic development on GHG emissions in the Baltic States (Latvia, Letonia, and Lithuania), and in Hungary, the Czech Republic, Slovakia, and Poland (the Visegrád Group or V4 countries) in the period of 1996-2019. The study introduces dynamic ARDL panels in the context of the traditional environmental Kuznets curve (EKC) and renewable Kuznets curve (RKC). The results indicated an inverse-N-shaped and a U-shaped pattern. Energy consumption and labour productivity enhanced pollution, while domestic credit to the private sector, as a share of GDP, and renewable energy consumption supported environmental protection. The implications of these results might help these countries to achieve the targets of the European Green Deal related to the reduction of pollution and the attainment of net zero emissions by 2050. However, national regulations should further promote the use of renewable energy sources.
\end{abstract}

Keywords: GHG emissions; economic growth; pollution; EKC; RKC

\section{Introduction}

Although the most developed communities are gradually moving into the postindustrial era [1], in the rest of the world industry is still an important driver of national economies [2]. This is particularly noticeable in the V4 countries and Baltic States, which are historically predetermined to deal with a low-skilled workforce, corrupted governance, and insufficient capital [3].

In order to enhance urban and industrial infrastructure sustainability, new tools are constantly being developed all over the world [4]. The latest advancements in environmentally friendly processes, such as water clarification [5], alternative energy sources from biowaste [6] and biomass [7,8], or carbon sequestration [9], have a well-proven ability to provide significant environmental and economic benefits. Nevertheless, the introduction of modern knowledge into these countries is delayed by scepticism, outdated legislation, lack of competence, and a dysfunctional market environment [10]. It was repeatedly and independently confirmed that these intensely populated and industrialized locations can be characterized as having high levels of gaseous pollutants, collectively known as greenhouse gases (GHG). Therefore, in an urban and industrial context, both private owners and society in general are interested in better understanding the environmental and economic impact of newly proposed measures [11].

Following the above, it is urgent to investigate the relationship between economic growth and pollution. The content of this work is split into several sections. In Section 1, the problem background and a short literature review are presented. Section 2 contains the data description as well as details of the proposed analytical approach. In Sections 3 and 4, 
respectively, the results of the analysis and the discussion are presented. A summary of the conducted research concludes the paper. The novelty of this research is given by the analysis of the economic growth-pollution nexus in the context of the European Green Deal, which requires the reduction of GHG emissions for all EU member states, including the V4 countries and Baltic States, before 2050. This type of analysis, based on a dynamic ARDL approach, allows us to make distinctions between short-run and long-run patterns of pollution, reflected by GHG emissions, economic growth, and other economic indicators such as labour productivity, domestic credit to private sector, and FDI. The European Green Deal targets are fixed for the long-run (net zero GHG emissions by 2050), but they could be achieved by short-term efforts. Therefore, the policy recommendations will take into account both short-run and long-run patterns to solve these issues in the short-term, or improve performance in a short period to achieve the long-run goals.

\subsection{Problem Background}

This section is related to the assessment of technologies, since pollution is closely related to their production and use. However, variables related to the particular characteristics of all technologies could not be included in the econometric model. Therefore, in this paper, the importance of economic factors in environmental protection are assessed using macroeconomic data. Muo and Azeez [12] argue that all new technologies that are coming into commercial scale application should be evaluated from a life cycle perspective (life cycle analysis, LCA). However, as advocated by Lampropoulos et al. [13], it should be better reflected that LCA assesses the impacts of technologies only to a limited extent and, most importantly, does not consider the economics, construction practices, material and labour costs, social and ethical aspects, etc. Due to the number of different disciplines and industries involved in assessing all of these factors, the overall assessment can vary significantly [14]. To make matters worse, it is not only the GHG emissions that can be perceived as a negative externality [15]. According to Maroušek et al. [16], industrial production is also strongly linked with the production of ultra-fine carbonaceous products of incomplete combustion that are collectively referred to as particulate matter (PM). PM is of note mainly because of its negative health impacts (as a transporter of noxious and even lethal ingredients). Nonetheless, climate change (albedo decline) is a cause for concern [17].

The prevailing assumption is that energy production plays a main role in GHG emissions [18]. Different energy sources (including solar, water, biomass, etc.) were repeatedly and independently investigated from techno-economical and environmental standpoints [19-21]. It should be noted that many developed countries are already in the process of abandoning fossil fuels [22,23]. Natural gas can be substituted by biogas [8,24], coal is being replaced by charred biowaste [25], and biodiesel or vegetable oil can be used instead of diesel $[23,26]$. While fossil fuels contribute to the additional release of GHG into the atmosphere, the new technologies discussed above are expected to support climate change mitigation [27]. Although the benefits and challenges have not yet been quantitively or qualitatively explored in an all-encompassing manner, Blazkova [28] assumed that the new generations of fuels will soon become cost competitive. Environmentally responsible production of renewable energy from biomass and biowaste requires investment associated with the minimization of pollutants that may occur under improper combustion conditions [29,30]. Khursheed et al. [31] recommended using elevated temperatures (additional increase by oxygen or pressurized air being the most common method) which resulted in better and more harmless combustion conditions (resulting in lower levels of GHG as well as PM). Hadzima et al. [32] argued that a similar effect may be achieved by co-combustion of biomass or biowaste with coal or charcoal. Still, all of these improvements needs to be addressed according to the actual prices of main energy commodities [33]. Stehel et al. [34] identified that additional financial benefits can be achieved by the prediction of prices according to the latest methods of mathematical modelling. Milward et al. [35] proposed multiple cyber networks enhanced by machine learning and data capturing systems that can obtain higher profits by utilizing smart, sustainable, and environmentally friendly 
technologies. Rowland et al. [36] proved that the use of advanced financial methods can stimulate the whole market and improve public opinions, resulting in warmer acceptance of innovative technologies. Machová and Vrbka [37] demonstrated that many environmentally friendly technologies are linked with biomass and agriculture in general, and therefore one can argue for their positive impact on the rural economy. Stehel et al. [38] reiterated that overall economic performance can be improved by energy recovery from both fossil and renewable energy sources.

\subsection{Related Studies}

The impact of economic development on GHG emissions remains a focus of scientists, practitioners, and a wide range of other stakeholders in various countries [39-43]. Enhanced energy efficiency, transition towards renewables, and reduced consumption are seen as key drivers towards more sustainable economic growth [44-46].

Economic growth and sustainable development are indispensable in relation to company social responsibility, as Androniceanu [47] demonstrated in research conducted in the field of bio-economics in Romania. Valodka et al. [48] applied a multiregional inputoutput method for the estimation of $\mathrm{CO}_{2}$ emissions due to in EU imports. Habib et al. [49] discussed an ARDL bounds testing approach for the analysis of environmental Kuznets curve. Ghauri et al. [50] used an autoregressive model with seasonal dummies and the Box-Jenkins methodology. The results of interesting research developed by the authors of [51-54] are based on a set of indicators that measure the economic value created by organizations that have made changes in their technologies to increase productivity and to reduce the degree of environmental pollution. There are also interesting concerns in the literature regarding how governments in European Union countries support their economic growth and sustainable development [55-57]. The team led by Androniceanu [58] identified the main clusters that group the analysed states by the impact of the measures taken by them to support sustainable economic growth.

\subsection{Analytical Tools}

In this work, a classic dynamic ARDL panel approach was used. There are numerous studies investigating the emission-growth nexus in different countries and different time periods which support our methodology.

In [59], the authors studied the long-run relationship between $\mathrm{CO}_{2}$ emissions, economic growth, energy use, and urbanization in Saudi Arabia. The period of 1971-2014 was considered and the ARDL approach, with structural brakes, was applied. The implications of financial development and the use of energy on $\mathrm{CO}_{2}$ emissions in the presence of economic growth between 1980 and 2014 in China are discussed in [60]. In this case, a nonlinear ARDL model was used to capture asymmetry arising from positive and negative components of financial development. The interconnection of growth, financial development, urbanization, and $\mathrm{CO}_{2}$ emissions in South Africa over the period of 1971-2016 was analysed in [61]. The ARDL long-term estimate was supported by the wavelet coherence approach, allowing for determination of the short- and long-run correlation and causality between variables at different periods and frequencies. In [62], the effect of financial development on $\mathrm{CO}_{2}$ emissions in Turkey was investigated. The period from 1960 to 2016 was considered, and the ARDL bounds test was used to examine the cointegration among the variables. The MINT countries (Mexico, Indonesia, Nigeria, and Turkey) were studied in [63]. The synergy between the aforementioned factors was analysed using yearly data from 1993 to 2017, and again the ARDL bounds test was employed.

That short review reveals that the ARDL approach was chosen as an analytical tool in all of the mentioned studies. Moreover, a systematic, in-depth comparison of the research methodologies used to analyse the emission-growth nexus described in $[60,61]$ further supported this observation. Taking this into account, a classic dynamic ARDL panel approach was used in the present work. 
For the sake of completeness, it should be mentioned that modern artificial intelligence and machine learning tools represent an interesting alternative [64]. Many of these were avoided by economists because of their lack of interpretability and transparency. Fortunately, the recently proposed, novel models can overcome these difficulties.

In [65], a multilayer neural network with specific interpretable layers was proposed. Those layers included: decision-tree-like splitting [66], dimension reduction, and persistent change filter for time series data. Additionally, a Lasso-type penalty on the parameters of the final layer was also used to improve model interpretability. The proposed approach was applied to panel data to predict monthly employment status, with administrative data from a city in China with a population of 4 million people. Problems related to the estimation of confidence intervals in neural networks were raised by Crane-Droesch [67] and Malte [68]. A feed-forward network, as an extension to cross-sectional and panel data models and to represent nonlinear components of that model, was proposed by Crane-Droesch. It was proven that such an approach is efficient, both for simulated data and for prediction of county-level corn yield using daily weather data. Malte demonstrated that the GDP growth rates of 24 industrialized economies followed a nonlinear time trend which could not be explained by autoregressive features or polynomial time variables. In such cases, a classic artificial neural network can be of use and, in this paper, a method for calculating marginal effects and confidence levels was proposed. The above examples, although not numerous, indicate that computational intelligence may become a serious alternative tool in applied econometrics.

\subsection{Environmental Kuznets Curve (EKC)}

The EKC links environmental degradation to economic development, supposing an increase and then a fall in pollution while the income per capita increases. A U-shaped pattern in EKC suggests a decrease in pollution, together with progress in economic development, followed by an increase in environmental degradation when economic growth surpasses a threshold. An inverted-U-shaped pattern implies more environmental degradation when economic growth increases, followed by a decline when economic growth reaches a specific threshold.

The economic growth-pollution nexus N-pattern states that when economic growth accelerates, pollution increases, then decreases while under a threshold of economic growth, being followed then by another increase. The inverted $\mathrm{N}$ relationship supposes a decrease in pollution, followed by an increase, and then a decline when economic growth accelerates.

Developing countries should also address environmental issues in their own strategies, given the differences in environmental policy implementation compared with developed states that Stern (2004) demonstrated [69]. There are two types of studies analysing EKC in developing countries: papers focusing on one country and papers analysing a group of countries. Our research focuses on a small number of developing EU member states located in Central and Eastern Europe. Most research uses $\mathrm{CO}_{2}$ as a proxy for air pollution, but, in this paper, we employ GHG emissions as the European Green Deal states that this indicator should reach net zero levels before 2050. In a recent study, Ali et al. (2021) used GHG emissions, ecological footprint, $\mathrm{CO}_{2}, \mathrm{CH}_{4}$, and $\mathrm{N}_{2} \mathrm{O}$ as proxies for pollution, and evaluated the impact of trade openness on pollution in OIC during the period 1991-2018 [70]. The results indicated that trade openness contributed to pollution in the case of all indicators, suggesting environmental degradation. In a study of $11 \mathrm{CEE}$ countries, including the countries analysed in our sample, Lazăr et al. (2019) revealed a positive impact of economic freedom, energy consumption, and labour productivity on $\mathrm{CO}_{2}$ emissions, and a negative effect of human development index on environmental degradation in the period 19962015 [71]. Individual studies indicated a relative decoupling between energy consumption and pollution in the Czech Republic [72] and a faster increase of economic growth compared with GHG emissions for Baltic States [73]. Recent studies highlighted the role of financial development, globalization, and recycling in EKC in order to propose the best strategies to reduce pollution [74-86]. 
Given this theoretical background, the main aim of this paper is to explain the GHG emissions in seven CEE countries using the EKC (environmental Kuznets curve) framework based on panel ARDL models. The objectives of the study are related to economic factors influencing pollution and policy proposals to reduce GHG emissions based on renewable energy consumption. The results support the hypothesis of decoupling between pollution and economic growth and reveals the role of renewable energy in environmental protection.

\section{Materials and Methods}

\subsection{Data}

This paper is based on a panel data approach conducted for seven CEE countries in the period from 1996 to 2019: the Czech Republic, Hungary, Poland, and the Slovak Republicwhich form the V4 countries-and Lithuania, Estonia and Latvia-which represent Baltic States. The economic growth and pollution nexus was studied in this region of Central and Eastern Europe using revised environmental Kuznets curves, where GHG emissions were used to measure the degree of pollution. Beside this dependent variable, the econometric models employed various explanatory variables:

- $\quad$ GHG emissions, in thousand tonnes $\mathrm{CO}_{2}$ equivalent, provided by Eurosta;

- Real GDP per capita in PPP (constant 2017 dollar) from the World Bank;

- Gross inland energy consumption per capita, in TOE per capita, based on Eurostat data;

- Share of renewable energy consumption in overall energy consumption at national level, from the World Bank;

- Share of foreign direct investment (FDI as net inflows) in GDP, provided by the World Bank;

- $\quad$ Output per worker as a proxy of labour productivity, from ILO;

- Domestic credit to private sector as a share of GDP, from the World Bank.

The Eurostat website [87], the World Bank website [88], and the ILO website [89] were used as sources of data.

The descriptive statistics associated with the data are presented in Table 1. The Czech Republic presented the maximum values for real GDP per capita in the entire period, while Latvia presented the lowest values of this indicator. The high standard of living in Czechia is due to intensive exports and high employment.

Table 1. Descriptive statistics ${ }^{1}$.

\begin{tabular}{|c|c|c|c|c|}
\hline Variable & Mean & $\begin{array}{l}\text { Standard } \\
\text { Deviation }\end{array}$ & Minimum & Maximum \\
\hline $\begin{array}{l}\text { GHG emissions } \\
\text { (GHG) }\end{array}$ & $90,884.52$ & $119,272.8$ & 59.71 & $422,764.3$ \\
\hline $\begin{array}{l}\text { Real GDP per capita } \\
\text { (GDP) }\end{array}$ & $24,433.86$ & 6912.45 & 9892.485 & $40,862.21$ \\
\hline $\begin{array}{l}\text { Share of energy consumption } \\
\text { (EC) }\end{array}$ & 3.098166 & 0.812457 & 1.382274 & 4.54796 \\
\hline FDI & 5.185719 & 8.279625 & 4.4143 & 54.2391 \\
\hline Labour productivity (LP) & $44,904.59$ & $17,941.57$ & $13,883.2$ & $80,539.48$ \\
\hline $\begin{array}{l}\text { Share of domestic credit to } \\
\text { private sector (DC) }\end{array}$ & 47.24903 & 16.63993 & 12.86938 & 58.8176 \\
\hline $\begin{array}{l}\text { Share of renewable energy } \\
\text { consumption (REC) }\end{array}$ & 16.63846 & 10.47484 & 3.630589 & 40.36562 \\
\hline
\end{tabular}

${ }^{1}$ Source: own computations made in Stata 15.

Poland was the leader in GHG emissions in the period 1996-2019, with the maximum value registered in 1997. This result is consistent with expectations since Poland has the fifth highest GHG emissions volume in the EU. Fossil fuel combustion is the main source of pollution in this state and causes almost 40,000 deaths per year.

Given this situation in Poland, the European Commission imposed a reduction target for GHG emissions in Poland of almost half, compared with the level in 2005. This target 
could be achieved by promoting renewable energy consumption. Therefore, the economic growth and pollution nexus is analysed using the traditional EKC, but also the RKC.

\subsection{Methodology}

The methodological approach starts from EKC for panel data, where GHG emissions (GHG) are explained using GDP (output) and few control variables:

$$
\mathrm{GHG}_{\mathrm{it}}=\alpha_{\mathrm{i}}+\beta_{1} \mathrm{GDP}_{\mathrm{it}}+\beta_{2} \mathrm{GDP}_{\mathrm{it}}^{2}+\beta_{3} \mathrm{GDP}_{\mathrm{it}}^{3}+\gamma \mathrm{X}_{\mathrm{it}}+\mathrm{e}_{\mathrm{it}}
$$

- $X_{i t}$ control variables

- $\beta_{1}, \beta_{2}, \beta_{3}, \gamma$ parameters

- $\alpha_{i}$ country-fixed effects

- $e_{i t}$ innovations

- $\quad i$-index indicating country

- $t$-index indicating year

The EKC is transformed to include renewable energy consumption (REC), which leads to the renewable Kuznets curve (RKC) that was described by Yao et al. [77]:

$$
\mathrm{GHG}_{\mathrm{it}}=\beta_{0}+\beta_{1} \mathrm{GDP}_{\mathrm{it}}+\beta_{2} \mathrm{GDP}_{\mathrm{it}}^{2}+\beta_{3} \mathrm{REC}_{\mathrm{it}}+\mathrm{e}_{\mathrm{it}}
$$

The Equation (2) is extended by including control variables:

$$
\mathrm{GHG}_{\mathrm{it}}=\beta_{0}+\beta_{2} \mathrm{GDP}_{\mathrm{it}}+\beta_{3} \mathrm{GDP}_{\mathrm{it}}^{2}+\beta_{4} \mathrm{REC}_{\mathrm{it}}+\gamma \mathrm{X}_{\mathrm{it}}+\mathrm{e}_{\mathrm{it}}
$$

Before panel data estimations, three properties of the panel data are analysed: crosssectional dependence, heterogeneity, and stationary. The CD Pesaran [78] test is used to check for cross-sectional dependence, which is obvious since the levels of GHG emissions and economic growth between countries are correlated due to regional spillovers. The null hypothesis associated to this test states the cross-sectional independence:

$$
H_{0}: \rho_{i j}=\rho_{j i}=\operatorname{cor}\left(e_{i t}, e_{j t}\right)=0 \text {, when } i \neq j H_{1}: \rho_{i j}=\rho_{j i} \neq 0 \text {, when some } i \neq j
$$

$\rho_{i j}$, the pair-wise correlation coefficient associated to errors, is given by:

$$
\rho_{i j}=\rho_{j i}=\frac{\sum_{t=1}^{T} e_{i t} \cdot e_{j t}}{\sqrt{\sum_{t=1}^{T} e_{i t}^{2}} \sqrt{\sum_{t=1}^{T} e_{j t}^{2}}}
$$

For balanced panels with $N$ countries, the test statistic is given by:

$$
C D=\sqrt{\frac{2}{N(N-1)}} \sum_{i=1}^{N-1} \sum_{j=i+1}^{N} \hat{\rho}_{i j}
$$

For countries denoted by $i$ and $j, T_{i j}$ represents the number of common observations:

$$
\hat{\rho}_{i j}=\hat{\rho}_{j i}=\frac{\sum_{t \in T_{i} \cap T_{j}}\left(\hat{e}_{i t}-\bar{e}_{i}\right)\left(\hat{e}_{j t}-\bar{e}_{j}\right)}{\sqrt{\sum_{t \in T_{i} \cap T_{j}}\left(\hat{e}_{i t}-\bar{e}_{i}\right)^{2}} \sqrt{\sum_{t \in T_{i} \cap T_{j}}\left(\hat{e}_{j t}-\bar{e}_{j}\right)^{2}}}
$$

where:

$$
\bar{e}_{i}=\frac{\sum_{t \in T_{i} \cap T_{j}}\left(\hat{e}_{i t}\right)}{\#\left(T_{i} \cap T_{j}\right)}
$$

Under cross-sectional dependence, the Breitung test is used for checking the existence of unit root. In the case of nonstationary data in level, the Pedroni and Westerlund tests are utilized to identify any long-term relationship between indicators. 
Under no cointegration, panel autoregressive distributed lag models (panel ARDL) are built. In this case, pooled mean group estimators (PMG) are proposed.

The basic panel ARDL models for environmental Kuznets curves (EKC, RKC) for country $i$ and year $t$ are given by:

$$
\begin{aligned}
& \mathrm{GHG}_{\mathrm{it}}=\alpha_{1 \mathrm{i}}+\sum_{\mathrm{l}=1}^{\mathrm{p}} \beta_{\mathrm{i} 110} \mathrm{GHG}_{\mathrm{it}-1}+\sum_{\mathrm{l}=0}^{\mathrm{q}} \beta_{\mathrm{il11}} \mathrm{GDP}_{\mathrm{it}-1}+ \\
& \sum_{l=0}^{\mathrm{q}} \beta_{\mathrm{il12}} \mathrm{GDP}^{2}{ }_{\mathrm{it}-1}+\sum_{\mathrm{l}=0}^{\mathrm{q}} \beta_{\mathrm{il13}} \mathrm{GDP}^{3}{ }_{\mathrm{it}-1}+\mathrm{e}_{1 \mathrm{it}} \\
& \mathrm{GHG}_{\mathrm{it}}=\alpha_{2 \mathrm{i}}+\sum_{\mathrm{l}=1}^{\mathrm{p}} \beta_{\mathrm{il} 20} \mathrm{GHG}_{\mathrm{it}-1}+\sum_{\mathrm{l}=0}^{\mathrm{q}} \beta_{\mathrm{il} 21} \mathrm{GDP}_{\mathrm{it}-1}+ \\
& \sum_{l=0}^{\mathrm{q}} \beta_{\mathrm{il} 22} \mathrm{GDP}^{2}{ }_{\mathrm{it}-1}+\sum_{\mathrm{l}=0}^{\mathrm{q}} \beta_{\mathrm{il} 23} \mathrm{REC}_{\mathrm{it}-1}+\mathrm{e}_{2 \mathrm{it}}
\end{aligned}
$$

The parameterization transforms the previous equations with $l$ indicating the lag:

$$
\begin{aligned}
\Delta \operatorname{lnGHG}_{i t}=\alpha_{1 i} & +\Phi_{1 i}\left(\ln \mathrm{GHG}_{i t-1}-\theta_{11} \ln G D P_{i t-1}-\theta_{12} \ln ^{2} G D P_{i t-1}\right. \\
& \left.+\theta_{13} \ln ^{3} G D P_{i t-1}\right)+\sum_{l=1}^{p-1} \lambda_{1 i l} \Delta \ln \mathrm{GHG}_{i t-l} \\
& +\sum_{l=0}^{q-1} \lambda_{1 i l}^{\prime} \Delta \ln \mathrm{GDP}_{i t-l} \\
& +\sum_{l=0}^{q-1} \lambda_{1 i l}^{\prime \prime} \Delta \ln ^{2} G D P_{i t-l}+\sum_{l=0}^{q-1} \lambda_{1 i l}^{\prime \prime \prime} \Delta \ln ^{3} G D P_{i t-l}+e_{1 i t} \\
\Delta \operatorname{lnGHG}_{i t}=\alpha_{2 i} \quad & +\Phi_{2 i}\left(\ln \mathrm{GHG}_{i t-1}-\theta_{21} \ln G D P_{i t-1}-\theta_{22} \ln ^{2} G D P_{i t-1}\right. \\
& \left.+\theta_{23} \ln R E C_{i t-1}\right)+\sum_{l=1}^{p-1} \lambda_{2 i l} \Delta \ln \mathrm{GHG}_{i t-l} \\
& +\sum_{l=0}^{q-1} \lambda_{2 i l}^{\prime} \Delta \ln \mathrm{GDP}_{i t-l} \\
& +\sum_{l=0}^{q-1} \lambda_{2 i l}^{\prime \prime} \Delta \ln ^{2} G D P_{i t-l}+\sum_{l=0}^{q-1} \lambda_{2 i l}^{\prime \prime \prime} \Delta \ln R E C_{i t-l}+e_{2 i t}
\end{aligned}
$$

$\lambda, \lambda^{\prime}, \lambda^{\prime \prime}, \lambda^{\prime \prime \prime}$ represent short-run coefficients associated to variables in the model, while $\theta$ reflects long-term coefficients of exogenous variables. $\Phi_{1 i}$ and $\Phi_{2 i}$ are speeds of adjustment.

The PMG estimator is indicated in this case because of homogenous long-term equilibrium across states in the sample associated to heterogeneous short-term connection. Moreover, under long-run homogeneity, the common correlated effect mean group estimator is efficient, but also consistent.

\section{Results}

The data series for all of the variables are transformed by using logarithm in order to achieve interpretations in terms of elasticity. The CD Pesaran's test is used to confirm the cross-sectional dependence in the case of variables in the model at $5 \%$ level of significance (see Table 2). Since the $p$-values are less than 0.05 , the independence hypothesis is rejected.

The application of the Breitung test suggests logarithm of GDP, GHG, labour productivity, and renewable energy consumption are stationary in the first difference. The data series for the rest of the variables are stationary in level (see Table 3). 
Table 2. The CD Pesaran's test-results (1996-2019) ${ }^{1}$.

\begin{tabular}{|c|c|c|}
\hline Variable & Statistic & $p$-Value \\
\hline ln_GDP & 21.92 & $<0.05$ \\
\hline ln_GHG & 2.32 & $<0.05$ \\
\hline ln_EC & 6.30 & $<0.05$ \\
\hline ln_FDI & 5.60 & $<0.05$ \\
\hline ln_LP & 21.84 & $<0.05$ \\
\hline $\ln \_D C$ & 2.19 & $<0.05$ \\
\hline ln_REC & 19.45 & $<0.05$ \\
\hline
\end{tabular}

${ }^{1}$ Source: own calculations in Stata 15.

Table 3. The Breitung test-results (1996-2019) ${ }^{1}$.

\begin{tabular}{|c|c|c|c|c|}
\hline Variable & $\begin{array}{c}\text { Statistic (Constant and } \\
\text { Trend) (No Lag) Data in } \\
\text { Level }\end{array}$ & $\begin{array}{l}\text { Statistic (Constant and } \\
\text { Trend) (One Lag) Data } \\
\text { in Level }\end{array}$ & $\begin{array}{l}\text { Statistic (Constant and } \\
\text { Trend) (No Lag) Data in } \\
\text { the First Difference }\end{array}$ & $\begin{array}{l}\text { Statistic (Constant and } \\
\text { Trend) (One Lag) Data } \\
\text { in the First Difference }\end{array}$ \\
\hline ln_GDP & -0.1403 & $-2.3502 *$ & $-4.5002 *$ & $-5.7298 *$ \\
\hline ln_GHG & -0.1279 & -0.8382 & $-3.6416^{*}$ & $-2.8106^{*}$ \\
\hline ln_EC & $-3.1173 *$ & $-2.6906^{*}$ & & \\
\hline ln_FDI & $-4.9810 *$ & $-4.0176^{*}$ & & \\
\hline ln_LP & 6.4658 & 2.9180 & $-4.6318 *$ & $-4.0683 *$ \\
\hline ln_DC & $-4.8820 *$ & $-4.2022 *$ & & \\
\hline ln_REC & 4.0165 & 1.4987 & $-6.6699 *$ & -2.8610 * \\
\hline
\end{tabular}

${ }^{1}$ Source: own calculations in Stata $15 .{ }^{*}$ Indicates less than $5 \%$.

The results of Pedroni and Westerlund tests for logarithm of GHG, GDP, labour productivity, and renewable energy consumption are mixed. The existence of a cointegration relationship is uncertain (see Table 4).

Table 4. Pedroni and Westerlund tests-results ${ }^{1}$.

\begin{tabular}{lcc}
\hline & Statistic & $p$-Value \\
\hline Pedroni test & & \\
Modified Phillips & 0.2627 & 0.3964 \\
Phillips & -1.8774 & 0.0302 \\
Augmented Dickey & -1.4996 & 0.0669 \\
Westerlund test & & \\
Variance ratio & -1.6039 & 0.0544 \\
\hline
\end{tabular}

${ }^{1}$ Source: own calculations in Stata 15.

The PMG estimations shown in Table 5 indicate a long-term convergence of the model with a discrepancy adjustment of estimation of $1.23 \%$ in EKC and $0.88 \%$ in RKC. An inverted-N pattern was observed for EKC and a U-shaped one for RKC.

The results indicated the role of renewable energy consumption in reducing pollution in the long-run, but not in the short-term. This observation suggests that it is necessary to promote more renewable energy in order to produce an efficient contribution to environmental protection. The EKC and RKC are not valid in the short-run.

The estimators in Table 6 confirm the overall capacity of renewable energy in reducing pollution. In this case, the impact of GDP growth on GHG emissions in RKC is higher than in PMG estimations. 
Table 5. Pool mean groups (PMG) regressions in basic EKC and RKC for V4 and Baltic countries ${ }^{1}$.

\begin{tabular}{lccc}
\hline & Variable & EKC & RKC \\
\hline \multirow{4}{*}{ Long-run relationship } & $\ln \_$GDP & $-1021.59^{*}$ & $-2.0183^{*}$ \\
& $\ln ^{2}$ _GDP & $101.1758^{*}$ & $0.1171^{*}$ \\
& $\ln ^{3}$ _GDP & $-3.338095^{*}$ & - \\
Error correction term & $\ln \_$REC & - & $-0.3282^{*}$ \\
& & $-1.2331^{*}$ & $-0.8842^{*}$ \\
Short-run relationship & $\ln$ _GDP & -3074.806 & -26.433 \\
& $\ln ^{2}$ _GDP & 309.7856 & 1.2930 \\
& $\ln ^{3}$ _GDP & -10.39557 & - \\
Residuals & $\ln \_$REC & - & 0.3054 \\
& Constant & 4251.86 & $18.207 *$ \\
\hline
\end{tabular}

${ }^{1}$ Source: own calculations in Stata 15. * Significant at $5 \%$ level of significance.

Table 6. Pesaran common correlated effects estimators in basic EKC and RKC for V4 and Baltic countries $^{1}$.

\begin{tabular}{lcc}
\hline & Variable & Coefficients \\
\hline & EKC & RKC \\
$\ln \_$GDP & $-114.573^{* *}$ & $-114.0228^{* *}$ \\
$\ln ^{2}$ _GDP & $5.817^{* *}$ & $5.836^{* *}$ \\
$\ln ^{3}$ _GDP & $-2.223^{* *}$ & $-0.476^{* *}$ \\
$\ln \_$REC & - & $58.498^{*}$ \\
Constant & 54.334 & . \\
\hline
\end{tabular}

${ }^{1}$ Source: own calculations in Stata $16 .{ }^{*}$ denotes significant at $5 \%$ level of significance. ${ }^{* *}$ denotes significant at $10 \%$ level of significance.

\section{Discussion}

The cross-sectional dependence in the data is justified by the fact that all of these economies were part of the same economic block before 1990 and then accessed the EU in 2004, thereby being subject to the same economic and environmental policies. However, a degree of heterogeneity remains due to differences in regional distribution, climate challenges, and national economic and environmental regulations that exceed the EU framework.

The inverted-N shape for EKC supports the decoupling between pollution and economic growth in the analysed sample. However, individual analysis of each country might suggest that this pattern is valid for some countries in the sample. LópezMenéndez et al. [80] indicated this pattern for the 27 EU countries in the period of 19962010, including the V4 countries and Baltic States. A cross-sectional analysis by Lazăr et al. (2019) indicated different patterns when pollution is reflected by $\mathrm{CO}_{2}$ emissions in a traditional EKC. For example, an inverted-N pattern was observed in the case of Poland and the Slovak Republic, while Estonia presented an N-pattern [71]. These results reveal that, in Estonia, economic growth is associated with environmental degradation, while in Slovakia and Poland economic development might be ensured with less pollution.

The inverted-N-shaped pattern was also previously observed for Italy in regional data for the period 1990-2001 in the case of industry and other sectors [81]. Another type of analysis should focus on the situation at the sectoral level, but this type of data is not available for sectors of the countries in our sample.

The U-shaped relationship is confirmed by the study of Yao et al. [77] of 17 developed and developing countries and of larger regions in the period from 1990-2014. The two types of patterns suggest progress in the decoupling of GHG emissions and economic growth, but insufficient efforts to reduce the pollution due to renewable energy consumption. This result indicated that the decrease in pollution is mostly attributed to factors other than renewable energy. Therefore, robustness is checked by adding control variables in the 
basic models. The country-level analysis for 1996-2015, where $\mathrm{CO}_{2}$ emissions were used to reflect the degree of pollution, indicated that Hungary and the Czech Republic followed an inverted-U pattern, suggesting that economic growth could be achieved with a decrease in pollution [71]. Latvia and Bulgaria could develop more from an economic point of view at the cost of higher $\mathrm{CO}_{2}$ emissions, while Slovenia and Romania did not present a clear pattern in the period of 1996-2015.

The complexity of shapes at the aggregated level suggests that a common policy for all of the countries in the sample is not recommended. Therefore, an individual analysis for each country should establish the type of pattern and the corresponding policies in each case. However, a traditional time series analysis is not indicated in this case because of the short period that could generate biased results. The EU has indicated targets for each country to achieve the common goal of reducing pollution, with an overall target of net zero emissions by 2050. This goal, promoted by the European Green Deal, might be achieved with specific energy policies to support sustainable development. On the other hand, the uncertainty regarding future economic development because of the COVID-19 pandemic could reduce economic activity and environmental tension related to pollution.

\section{Robustness}

The models, including additional variables, are presented below. The models for RKC were based on labour productivity, share of domestic credit to private sector, and share of FDI. The EKC model was extended to include these variables, plus share of energy consumption (see Table 7). The speeds of adjustment were lower in these cases. The previous patterns were confirmed and EKC and RKC are valid in the long-run. The impact of FDI on pollution was not statistically significant because of lower interest of foreign investors in these developing countries, compared with developed ones. Domestic credit to private sector contributed to a reduction in pollution, which might indicate that funds are assigned with priority to environmentally friendly projects. Labour productivity enhanced pollution, while energy consumption raised the level of GHG emissions. One solution to achieve the European Green Deal Targets would be the consumption of more renewable energy, but an extreme utilisation of renewable sources is not recommended by policy-makers.

Table 7. Pool mean groups regressions in extended EKC and RKC for the V4 and Baltic countries ${ }^{1}$.

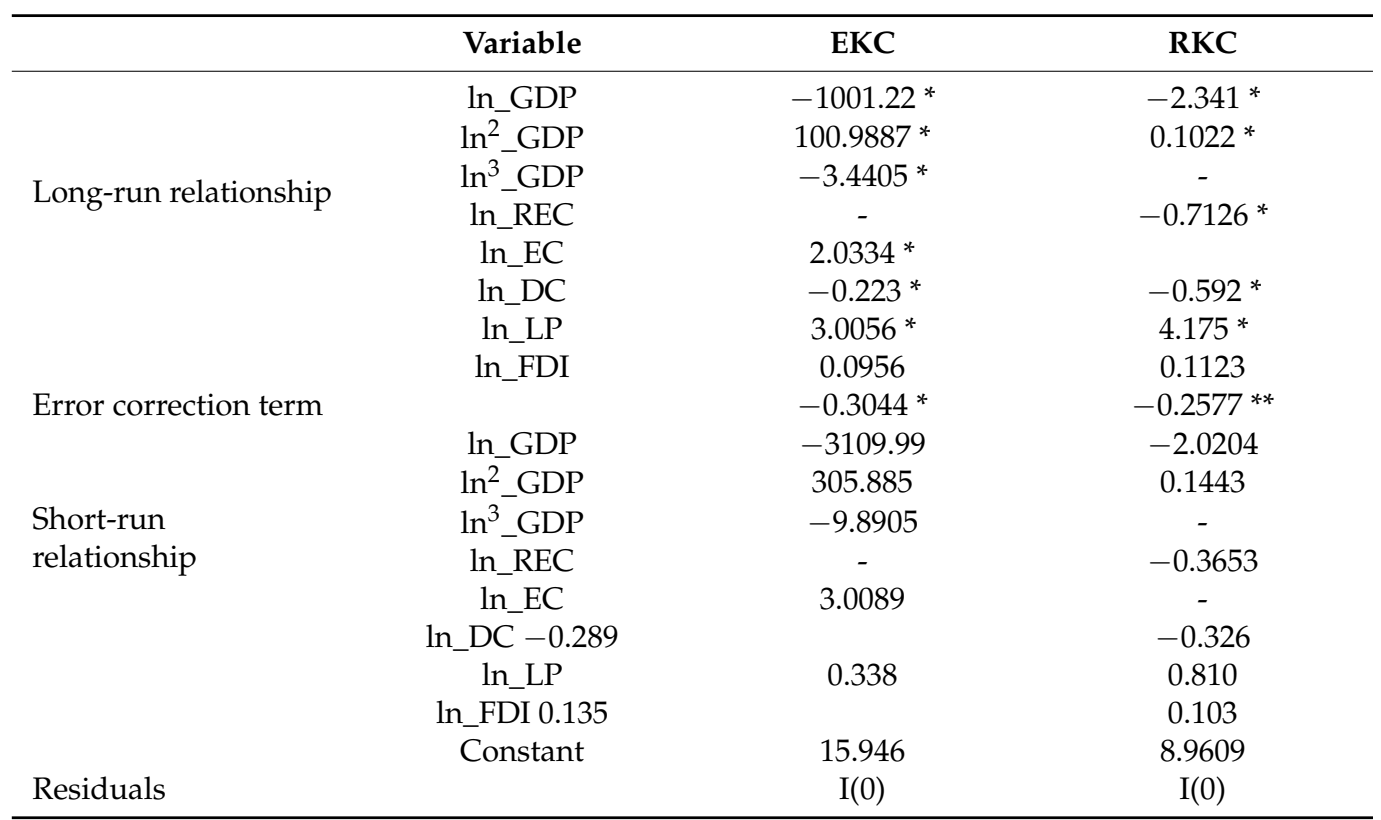

${ }^{1}$ Source: own calculations in Stata $15 .{ }^{*}$ Significant at $5 \%$ level of significance. ${ }^{* *}$ Significant at $10 \%$ level of significance. 
Table 8 confirms the inverted N- and U-patterns for EKC and RKC. Domestic credit to private sector is essential for business development, but environmental regulations gave priority to sustainable development. According to economic theory, the development of the financial sector in a certain country ensures the premise for FDI attraction and, consequently, the acceleration of economic growth. However, credit for business development should be attributed to sustainable projects that encourage environmental protection. Labour productivity contributed to pollution as Simionescu et al. [82] demonstrated for the 28 EU countries from 2007 to 2019. Green technology could reduce labour productivity and significantly contribute to the growth of environmental quality. The new challenges for green and digital economies will ensure new jobs in less pollutant sectors. However, investment in new technologies, and in human capital to develop digital skills, is necessary to overcome the difficulties of transitioning an unqualified labour force out of polluting sectors.

Table 8. Pesaran common correlated effects estimators in extended ERK and RKC for V4 and Baltic countries ${ }^{1}$.

\begin{tabular}{|c|c|c|}
\hline \multirow[t]{2}{*}{ Variable } & \multicolumn{2}{|c|}{ Coefficients } \\
\hline & EKC & RKC \\
\hline $\ln _{-} \mathrm{GDP}_{\mathrm{t}}$ & $-2.751^{* *}$ & $-50.5425^{* *}$ \\
\hline $\ln ^{\overline{2}}$ _GDP & $0.310^{* *}$ & $2.568 * *$ \\
\hline $\ln ^{3}$ GDP & $-2.678^{* *}$ & - \\
\hline ln_REC & - & \\
\hline ln_EC & $0.988^{* *}$ & $-0.934^{* *}$ \\
\hline ln_DC & $-1.060 * *$ & $-1.093^{* *}$ \\
\hline ln_LP & $0.205^{* *}$ & 3.651 \\
\hline ln_FDI & 0.0087 & 0.018 \\
\hline Constant & 70.225 & -389.218 \\
\hline
\end{tabular}

${ }^{1}$ Source: own calculations in Stata $15 .{ }^{* *}$ Significant at $10 \%$ level of significance.

The GHG emissions and energy consumption nexus is also valid for developing countries. In the case of these developing countries, fossil fuels are intensively used, which negatively affects energy efficiency and is harmful for the environment. The positive effects of energy consumption on pollution was confirmed by Lazăr et al. [71] (2019) for more CEEs in the period of 1996-2015. The analysed countries include the V4 and Baltic countries, and $\mathrm{CO}_{2}$ emissions were investigated instead of GHG emissions. The same paper demonstrated that FDI is not relevant when explaining pollution in these states. For Czechia, Hungary, Poland, and Slovakia, few studies indicated the role of FDI in enhancing economic growth [83-85], but it seems that the technologies were environmentally friendly and did not increase GHG emissions.

\section{Conclusions}

In this work, a study of the impact of economic growth on GHG emissions in a sample of Central and Eastern European (CEE) countries (the V4 countries, as well as Lithuania, Estonia, and Latvia) in the period of 1996-2019 was presented. For analysis, a dynamic ARDL panel approach was used, this method being used in other similar studies for countries such as South Africa, China, Saudi Arabia, Turkey, and the MINT countries [59-64]. This method presents the benefit of reducing endogeneity. Compared with other papers that employed ARDL models for only one country using a time series (Saudi Arabia in Raggad (2018) and South Africa in Ahmad et al. (2018)), our approach was based on ARDL models on panel data [59,61]. Panel ARDL models could be used only in cases of non-cointegrated series, as in this case, and allowed us to explain both short-run and long-run relationships between GHG growth and the explanatory variables. A similar study based on panel ARDL for the V4 countries, Romania, and Bulgaria was made by Simionescu et al. (2021) for the period 1996-2019. The authors obtained an N-shaped link between GHG and GDP per capita and a U-shaped relationship for the renewable 
Kuznets curve. In this case, policies were recommended to increase renewable energy consumption, and to reduce labour productivity and credit to the private sector, in order to achieve the European Green Deal targets and decrease GHG emissions [86]. Our results are similar to these since renewable energy consumption and less labour productivity reduces pollution. However, in our case, credit to the private sector also contributed to environmental protection since, in Baltic countries, this type of funding is mostly assigned to environmental projects.

The PMG estimator is suitable in this case because of the low number of countries and because of the existence of long-run homogeneity. Moreover, common correlated models were proposed in order to decrease the contemporaneous correlation. A comparative analysis between developed countries and these developing countries could be made in order to check for differences or similarities in patterns. The main limit of the study is related to the analysis of a short period of time due to data availability. The study is restricted to a panel data analysis because of the small number of countries and short period. This approach does not allow us to observe developments in individual countries and point out specifics within these. Other methods, such as Bayesian models, would be necessary to obtain information of greater importance and relevance to decision-makers in formulating and evaluating energy and climate policies.

Generalization of the results could not be made for other emerging economies since there are other factors that might influence pollution (e.g., environmental regulations and quality of governance). These factors might also be considered in a future study for the V4 countries and Baltic States.

The results present policy implications. The objectives of the European Green Deal could be achieved when renewable energy consumption is enhanced. Moreover, policy recommendations are suggested to promote FDI projects that assign priority to environmental protection.

The above discussion proves that the used methodology is correct and that all of the conclusions presented in Section 4 are reasonable. For further insight into the analysed data, other analytical tools, e.g., those based on machine learning, could be of use. This research direction will be investigated in the future.

Author Contributions: Conceptualization, M.S. and M.R.; methodology, M.S.; software, M.S.; validation, M.S., A.T., and A.W.; formal analysis, M.S.; investigation, M.S.; resources, A.T. and A.W.; data curation, M.S.; writing—original draft preparation, M.S., A.W., A.T., and M.R.; writing-review and editing, M.S.; visualization, A.W.; supervision, A.T.; project administration, A.T. and A.W.; funding acquisition, A.T., A.W., and M.R. All authors have read and agreed to the published version of the manuscript.

Funding: This research was funded by National Center for Research and Development, Poland, grant no. POIR.01.01.01-00-0281/20-00, entitled Predictive energy management system EnMS.

Institutional Review Board Statement: Not applicable.

Informed Consent Statement: Not applicable.

Data Availability Statement: Data are available by request.

Conflicts of Interest: The authors declare no conflict of interest.

\section{References}

1. Peters, E.; Kliestik, T.; Musa, H.; Durana, P. Product decision-making information systems, real-time big data analytics, and deep learning-enabled smart process planning in sustainable industry 4.0. J. Self-Gov. Manag. Econ. 2020, 8, 16-22.

2. Kliestik, T.; Misankova, M.; Valaskova, K.; Svabova, L. Bankruptcy prevention: New effort to reflect on legal and social changes. Sci. Eng. Ethics 2018, 24, 791-803. [CrossRef]

3. Kovacova, M.; Kliestik, T.; Valaskova, K.; Durana, P.; Juhaszova, Z. Systematic review of variables applied in bankruptcy prediction models of Visegrad group countries. Oeconomia Copernic. 2019, 10, 743-772. [CrossRef]

4. Lenhard, R.; Malcho, M.; Jandačka, J. Modelling of heat transfer in the evaporator and condenser of the working fluid in the heat pipe. Heat Transf. Eng. 2019, 40, 215-226. [CrossRef] 
5. Maroušek, J.; Stehel, V.; Vochozka, M.; Kolář, L.; Maroušková, A.; Strunecký, O.; Peterka, J.; Kopecký, M.; Shreedhar, S. Ferrous sludge from water clarification: Changes in waste management practices advisable. J. Clean. Prod. 2019, 218, 459-464. [CrossRef]

6. Mardoyan, A.; Braun, P. Analysis of Czech subsidies for solid biofuels. Int. J. Green Energy 2015, 12, 405-408. [CrossRef]

7. Jandačka, J.; Mičieta, J.; Holubčík, M.; Nosek, R. Experimental Determination of Bed Temperatures during Wood Pellet Combustion. Energy Fuels 2017, 31, 2919-2926. [CrossRef]

8. Svazas, M.; Navickas, V.; Krajnakova, E.; Nakonieczny, J. Sustainable supply chain of the biomass cluster as a factor for preservation and enhancement of forests. J. Int. Stud. 2019, 12, 309-321. [CrossRef]

9. Maroušek, J.; Strunecký, O.; Kolář, L.; Vochozka, M.; Kopecký, M.; Maroušková, A.; Batt, J.; Poliak, M.; Šoch, M.; Bartoš, P.; et al. Advances in nutrient management make it possible to accelerate biogas production and thus improve the economy of food waste processing. Energy Sources Part A Recovery Util. Environ. Eff. 2020, 1-10. [CrossRef]

10. Kliestik, T.; Valaskova, K.; Nica, E.; Kovacova, M.; Lazaroiu, G. Advanced methods of earnings management: Monotonic trends and change-points under spotlight in the Visegrad countries. Oeconomia Copernic. 2020, 11, 371-400. [CrossRef]

11. Valaskova, K.; Throne, O.; Kral, P.; Michalkova, L. Deep learning-enabled smart process planning in cyber-physical system-based manufacturing. J. Self-Gov. Manag. Econ. 2020, 8, 121-127.

12. Muo, I.; Azeez, A.A. Green entrepreneurship: Literature review and agenda for future research. Int. J. Entrep. Knowl. 2019, 7, 17-29. [CrossRef]

13. Lampropoulos, G.; Siakas, K.; Anastasiadis, T. Internet of things in the context of industry 4.0: An overview. Int. J. Entrep. Knowl. 2019, 7, 4-19. [CrossRef]

14. Cepel, M. Social and Cultural Factors and their Impact on the Quality of Business Environment in the SME Segment. Int. J. Entrep. Knowl. 2019, 7, 65-73. [CrossRef]

15. Vatankhah, S.; Zarra-Nezhad, M.; Amirnejad, G. An empirical assessment of willingness to accept "low-cost" air transport services: Evidence from the Middle East. J. Tour. Serv. 2019, 10, 79-103. [CrossRef]

16. Maroušek, J.; Maroušková, A.; Kůs, T. Shower cooler reduces pollutants release in production of competitive cement substitute at low cost. Energy Sources Part A Recovery Util. Environ. Eff. 2020, 1-10. [CrossRef]

17. Vu, H.M.; Ngo, V.M. Strategy development from triangulated viewpoints for a fast growing destination toward sustainable tourism development-A case of Phu Quoc Islands in Vietnam. J. Tour. Serv. 2019, 10, 117-140. [CrossRef]

18. Biagi, G.; Bertaccini, B. Public Information and Perception of the Environmental Risk about the Works for the City High Speed Railroad Underpass in Florence, Italy. J. Tour. Serv. 2018, 9. [CrossRef]

19. Haskova, S. Holistic assessment and ethical disputation on a new trend in solid biofuels. Sci. Eng. Ethics 2017, 23, 509-519. [CrossRef]

20. Streimikiene, D. Ranking of Baltic States on progress towards the main energy security goals of European energy union strategy. J. Int. Stud. 2020, 13, 24-37. [CrossRef] [PubMed]

21. Štreimikienè, D. Externalities of power generation in Visegrad countries and their integration through support of renewables. Econ. Sociol. 2021, 14, 89-102. [CrossRef]

22. Bencsik, A.; Kosár, S.T.; Machová, R. Corporate Culture in Service Companies that Support Knowledge Sharing. J. Tour. Serv. 2018, 9, 7-13. [CrossRef]

23. Vo, H.D. Sustainable agriculture \& energy in the U.S.: A link between ethanol production and the acreage for corn. Econ. Sociol. 2020, 13, 259-268. [CrossRef]

24. Achinas, S.; Achinas, V.; Euverink, G.J.W. A technological overview of biogas production from biowaste. Engineering 2017, 3 , 99-307. [CrossRef]

25. Vochozka, M.; Maroušková, A.; Váchal, J.; Straková, J. Reengineering the paper mill waste management. Clean Technol. Environ. Policy 2016, 18, 323-329. [CrossRef]

26. Vochozka, M.; Rowland, Z.; Suler, P.; Marousek, J. The influence of the international price of oil on the value of the EUR/USD exchange rate. J. Compet. 2020, 12, 167. [CrossRef]

27. Calvo, J. High-Tech Start-Ups in Japan: Cogent Labs, AI-OCR Solutions for Automated Business Process Outsourcing. Int. J. Entrep. Knowl. 2018, 6, 12-31. [CrossRef]

28. Blažková, I. Sectoral and firm-level determinants of profitability: A multilevel approach. Int. J. Entrep. Knowl. 2018, 6, 32-44. [CrossRef]

29. Nefzi, N. Fear of failure and entrepreneurial risk perception. Int. J. Entrep. Knowl. 2018, 6, 45-58. [CrossRef]

30. Hnatyshyn, M. Decomposition analysis of the impact of economic growth on ammonia and nitrogen oxides emissions in the European Union. J. Int. Stud. 2018, 11, 201-209. [CrossRef]

31. Khursheed, A.; Mustafa, F.; Fatima, M.; Siddique, F. Entrepreneurial intentions: Gem based emipirical analysis on the Northern Europe and Asian countries. Int. J. Entrep. Knowl. 2018, 6, 59-70. [CrossRef]

32. Hadzima, B.; Janeček, M.; Estrin, Y.; Kim, H.S. Microstructure and corrosion properties of ultrafine-grained interstitial free steel. Mater. Sci. Eng. A 2007, 462, 243-247. [CrossRef]

33. Vochozka, M.; Horák, J.; Šuleř, P. Equalizing seasonal time series using artificial neural networks in predicting the Euro-Yuan exchange rate. J. Risk Financ. Manag. 2019, 12, 76. [CrossRef]

34. Stehel, V.; Rowland, Z.; Mareček, J. Valuation of Intangible Assets Deposit Into Capital Company in Case of Specific Transaction. AD Alta J. Interdiscip. Res. 2019, 9, 287-291. 
35. Milward, R.; Popescu, G.H.; Michalikova, K.F.; Musova, Z.; Machova, V. Sensing, smart, and sustainable technologies in Industry 4.0: Cyber-physical networks, machine data capturing systems, and digitized mass production. Econ. Manag. Financ. Mark. 2019, $14,37-43$.

36. Rowland, Z.; Machová, V.; Horák, J.; Hejda, J. Determining the Market Value of the Enterprise Using the Modified Method of Capitalized Net Incomes and Metfessel Allocation of Input Data. AD Alta J. Interdiscip. Res. 2019, 9, 305-310.

37. Machová, V.; Jaromír, V. Value generators for businesses in agriculture. In Proceedings of the 12th International Days of Statistics and Economics Conference Proceedings, Prague, the 11th of October 2018; Löster, T., Pavelka, T., Eds.; Libuše Macáková, Melandrium: Praha, Česká Republika, 2018; pp. 1123-1132, ISBN 978-80-87990-14-8.

38. Stehel, V.; Horák, J.; Vochozka, M. Prediction of institutional sector development and analysis of enterprises active in agriculture. E M Ekon. Manag. 2019, 22. [CrossRef]

39. Alkhateeb, T.T.Y.; Mahmood, H.; Altamimi, N.N.; Furqan, M. Role of education and economic growth on the $\mathrm{CO}_{2}$ emissions in Saudi Arabia. Entrep. Sustain. Issues 2020, 8, 195-209. [CrossRef]

40. Zamil, A.M.A.; Furqan, M.; Mahmood, H. Trade openness and $\mathrm{CO}_{2}$ emissions nexus in Oman. Enterp. Sustain. Issues 2019, 7, 1319-1329. [CrossRef]

41. Igaliyeva, L.; Niyazbekova Sh, S.; Serikova, M.; Kenzhegaliyeva, Z.; Mussirov, G.; Zueva, A.; Tyurina, Y.U.; Maisigova, L. Towards environmental security via energy efficiency: A case study. Entrep. Sustain. Issues 2020, 7, 3488-3499. [CrossRef]

42. Sneideriene, A.; Viederyte, R. Green growth assessment discourse on evaluation indices in the European Union. Entrep. Sustain. Issues 2020, 8, 360-369. [CrossRef]

43. Chehabeddine, M.; Tvaronavičienè, M. Securing regional development. Insights Reg. Dev. 2020, 2, 430-442. [CrossRef]

44. Sarma, U.; Karnitis, G.; Zuters, J.; Karnitis, E. District heating networks: Enhancement of the efficiency. Insights Reg. Dev. 2019, 1, 200-213. [CrossRef]

45. El Iysaouy, L.; El Idrissi, N.E.; Tvaronavičienė, M.; Lahbabi, M.; Oumnad, A. Towards energy efficiency: Case of Morocco. Insights Reg. Dev. 2019, 1, 259-271. [CrossRef]

46. Tvaronavičienè, M.; Prakapienè, D.; Garškaitè-Milvydienè, K.; Prakapas, R.; Nawrot, Ł. Energy Efficiency in the Long-Run in the Selected European Countries. Econ. Sociol. 2018, 11, 245-254. [CrossRef]

47. Androniceanu, A. Social responsibility, an essential strategic option for a sustainable development in the field of bio-economy. Amfiteatru Econ. 2019, 21, 503-519. [CrossRef]

48. Valodka, I.; Snieska, V.; Mihi-Ramirez, A. Impact of the International Trade on the EU Clothing Industry Carbon Emissions. Inz. Ekon. Eng. Econ. 2020, 31, 314-322. [CrossRef]

49. Habibur, R.; Ghazali, A.; Bhatti, G.A.; Khan, S.U. Role of Economic Growth, Financial Development, Trade, Energy and FDI in Environmental Kuznets Curve for Lithuania: Evidence from ARDL Bounds Testing Approach. Inz. Ekon. Eng. Econ. 2020, 31, 39-49. [CrossRef]

50. Ghauri, S.P.; Ahmed, R.R.; Streimikiene, D.; Streimikis, J. Forecasting Exports and Imports by using Autoregressive (AR) with Seasonal Dummies and Box-Jenkins Approaches: A Case of Pakistan. Inz. Ekon. Eng. Econ. 2020, 31, 291-301. [CrossRef]

51. Tamulevičienè, D.; Androniceanu, A. Selection of the indicators to measure an enterprise's value and its changes in the controlling system for medium-sized enterprises. Entrep. Sustain. Issues 2020, 7, 1440-1458. [CrossRef]

52. Chovancová, J.; Tej, J. Decoupling economic growth from greenhouse gas emissions: The case of the energy sector in V4 countries Equilib. Q. J. Econ. Econ. Policy 2020, 15, 235-251. [CrossRef]

53. Filimonova, I.; Komarova, A.; Mishenin, M. Impact of the global green factor on the capitalization of oil companies in Russia. Oeconomia Copernic. 2020, 11, 309-324. [CrossRef]

54. Jonek-Kowalska, I. Transformation of energy balances with dominant coal consumption in European economies and Turkey in the years 1990-2017. Oeconomia Copernic. 2019, 10, 627-647. [CrossRef]

55. Karnitis, G.; Karnitis, E. Sustainable growth of EU economies and Baltic context: Characteristics and modelling. J. Int. Stud. 2017, 10, 209-224. [CrossRef] [PubMed]

56. Stavytskyy, A.; Kharlamova, G.; Giedraitis, V.; Šumskis, V. Estimating the interrelation between energy security and macroeconomic factors in European countries. J. Int. Stud. 2018, 11, 217-238. [CrossRef] [PubMed]

57. Shindina, T.; Streimikis, J.; Sukhareva, Y.; Nawrot, Ł. Social and Economic Properties of the Energy Markets. Econ. Sociol. 2018, 11, 334-344. [CrossRef]

58. Androniceanu, A.; Kinnunen, J.; Georgescu, I. E-Government Clusters in the EU Based on the Gaussian Mixture Models. Adm. Si Manag. Public 2020, 35, 6-20. Available online: https://ramp.ase.ro/_data/files/articole/2020/35-01.pdf (accessed on 3 February 2021). [CrossRef]

59. Raggad, B. Carbon dioxide emissions, economic growth, energy use, and urbanization in Saudi Arabia: Evidence from the ARDL approach and impulse saturation break tests. Environ. Sci. Pollut. Res 2018, 25, 14882-14898. [CrossRef] [PubMed]

60. Ahmad, M.; Khan, Z.; Ur Rahman, Z.; Khan, S. Does financial development asymmetrically affect $\mathrm{CO}_{2}$ emissions in China? An application of the nonlinear autoregressive distributed lag (NARDL) model. Carbon Manag. 2018, 9, 631-644. [CrossRef]

61. Adebayo, T.S.; Odugbesan, J.A. Modeling $\mathrm{CO}_{2}$ emissions in South Africa: Empirical evidence from ARDL based bounds and wavelet coherence techniques. Environ. Sci. Pollut. Res. 2021, 28, 9377-9389. [CrossRef]

62. Rjoub, H.; Odugbesan, J.A.; Adebayo, T.S.; Wong, W.K. Sustainability of the moderating role of financial development in the determinants of environmental degradation: Evidence from Turkey. Sustainability 2021, 13, 1844. [CrossRef] 
63. Odugbesan, J.A.; Rjoub, H. Relationship among economic growth, energy consumption, $\mathrm{CO}_{2}$ emission, and urbanization: Evidence from MINT countries. Sage Open 2020, 10, 2158244020914648. [CrossRef]

64. Staniucha, R.; Wojciechowski, A. Mouth Features Extraction for Emotion Analysis. In Hard and Soft Computing for Artificial Intelligence, Multimedia and Security. ACS 2016. Advances in Intelligent Systems and Computing; Kobayashi, S., Piegat, A., Pejaś, J., El Fray, I., Kacprzyk, J., Eds.; Springer: Cham, Switzerland, 2017; Volume 534. [CrossRef]

65. Yang, Y.; Zheng, Z.; Weinan, E. Interpretable Neural Networks for Panel Data Analysis in Economics. arXiv 2020, arXiv:abs/2010.05311. [CrossRef]

66. Półrola, M.; Wojciechowski, A. Real-Time Hand Pose Estimation Using Classifiers. In Computer Vision and Graphics. ICCVG 2012. Lecture Notes in Computer Science; Bolc, L., Tadeusiewicz, R., Chmielewski, L.J., Wojciechowski, K., Eds.; Springer: Berlin/Heidelberg, Germany, 2012; Volume 7594. [CrossRef]

67. Crane-Droesch, A. Semiparametric panel data models using neural networks. Applications 2017, arXiv:1702.06512.

68. Malte, J. Artificial neural network regression models in a panel setting: Predicting economic growth. Econ. Model. 2020, 91, 148-154.

69. Stern, D.I. The rise and fall of the environmental Kuznets curve. World Dev. 2004, 32, 1419-1439. [CrossRef]

70. Ali, S.; Yusop, Z.; Kaliappan, S.R.; Chin, L. Trade-environment nexus in OIC countries: Fresh insights from environmental Kuznets curve using GHG emissions and ecological footprint. Environ. Sci. Pollut. Res. 2021, 28, 4531-4548. [CrossRef]

71. Lazăr, D.; Minea, A.; Purcel, A.A. Pollution and economic growth: Evidence from Central and Eastern European countries. Energy Econ. 2019, 81, 1121-1131. [CrossRef]

72. Solilová, V.; Nerudová, D. Evaluation of greenhouse gas emissions and related aspects: Case of the Czech Republic. Acta Univ. Agric. Silvic. Mendel. Brun. 2015, 63, 281-292. [CrossRef]

73. Štreimikienè, D.; Balezentis, T. Kaya identity for analysis of the main drivers of GHG emissions and feasibility to implement EU "20-20-20" targets in the Baltic States. Renew. Sustain. Energy Rev. 2016, 58, 1108-1113. [CrossRef]

74. Destek, M.A.; Sarkodie, S.A. Investigation of environmental Kuznets curve for ecological footprint: The role of energy and financial development. Sci. Total Environ. 2019, 650, 2483-2489. [CrossRef]

75. Wang, Q.; Wei, H.H.; Xu, Q. A solid oxide fuel cell (SOFC)-based biogas-from-waste generation system for residential buildings in China: A feasibility study. Sustainability 2018, 10, 2395. [CrossRef]

76. Suki, N.M.; Sharif, A.; Afshan, S.; Suki, N.M. Revisiting the Environmental Kuznets Curve in Malaysia: The role of globalization in sustainable environment. J. Clean. Prod. 2020, 264, 121669. [CrossRef]

77. Yao, S.; Zhang, S.; Zhang, X. Renewable energy, carbon emission and economic growth: A revised environmental Kuznets Curve perspective. J. Clean. Prod. 2019, 235, 1338-1352. [CrossRef]

78. Pesaran, M.H. General diagnostic tests for cross-sectional dependence in panels. Empir. Econ. 2021, 60, 13-50. [CrossRef]

79. Pesaran, M.H. Estimation and inference in large heterogeneous panels with a multifactor error structure. Econometrica 2006, 74, 967-1012. [CrossRef]

80. López-Menéndez, A.J.; Pérez, R.; Moreno, B. Environmental costs and renewable energy: Re-visiting the Environmental Kuznets Curve. J. Environ. Manag. 2014, 145, 368-373. [CrossRef] [PubMed]

81. Mazzanti, M.; Montini, A.; Zoboli, R. Economic Dynamics, Emission Trends and the EKC Hypothesis: New Evidence Using NAMEA and Provincial Panel Data for Italy; No. 10261; Fondazione Eni Enrico Mattei (FEEM): Basilicata, Italy, 2007.

82. Simionescu, M.; Bilan, Y.; Zawadzki, P.; Wojciechowski, A.; Rabe, M. GHG Emissions Mitigation in the European Union Based on Labor Market Changes. Energies 2021, 14, 465. [CrossRef]

83. Fifeková, E.; Nemcová, E. Impact of FDI on economic growth: Evidence from V4 countries. Period. Polytech. Soc. Manag. Sci. 2015, 23, 7-14. [CrossRef]

84. Gural, A.; Lomachynska, I. FDI and financial development as determinants of economic growth for V4 countries. Balt. J. Econ. Stud. 2017, 3, 59-64. [CrossRef]

85. Vasylieva, T.; Lyulyov, O.; Bilan, Y.; Streimikiene, D. Sustainable economic development and greenhouse gas emissions: The dynamic impact of renewable energy consumption, GDP, and corruption. Energies 2019, 12, 3289. [CrossRef]

86. Simionescu, M.; Păuna, C.B.; Niculescum, M.D.V. The Relationship between Economic Growth and Pollution in Some New European Union Member States: A Dynamic Panel ARDL Approach. Energies 2021, 14, 2363. [CrossRef]

87. The Eurostat Website. Available online: https:/ / ec.europa.eu/eurostat/en/web/main/data/database (accessed on 2 February 2021).

88. World Bank Website. Available online: https:/ / data.worldbank.org (accessed on 3 February 2021).

89. ILO Website. Available online: https://ilostat.ilo.org/topics/labour-productivity (accessed on 1 February 2021). 